\title{
Nitrification rates related to sedimentary structures in an Atlantic intertidal mudflat, Marennes-Oléron Bay, France
}

\author{
M. J. C. Laima ${ }^{1, *}$, M. F. Girard ${ }^{2}$, F. Vouvé ${ }^{2}$, P. Richard ${ }^{2}$, G. Blanchard ${ }^{3}$, D. Gouleau ${ }^{2}$ \\ 'Aarhus University, Department of Earth Sciences, Ny Munkegade, Building 520, 8000 Aarhus C, Denmark \\ ${ }^{2}$ CREMA, CNRS-IFREMER, Place du Séminaire, BP 5, 17137 L'Houmeau, France \\ ${ }^{3}$ University of La Rochelle, Department of Biology, LBBM, 17042 La Rochelle, France
}

\begin{abstract}
Rates of actual nitrification through acetylene blockage of $\mathrm{NH}_{4}{ }^{+}$oxidation and potential nitrification were measured in 2 intertidal geomorphological structures, 'ridges and runnels', at Marennes-Oléron Bay, France. Nitrification rates were 6 times higher in runnels as compared to ridges and their $\mathrm{O}_{2}$ gradients with depth were different. Calculated $\mathrm{N}$ mineralization rates averaged $1.66 \mathrm{mmol} \mathrm{m}^{-2} \mathrm{~d}^{-1}$ in runnels versus $0.29 \mathrm{mmol} \mathrm{m}^{-2} \mathrm{~d}^{-1}$ in ridges: Over $70 \%$ of this produced $\mathrm{NH}_{4}{ }^{+}$was nitrified and thus became potentially available for denitrification. In neither ridges nor runnels was there a significant correlation between potential nitrification and $\mathrm{pH}, \mathrm{E}_{\mathrm{h}}$ or pore water $\mathrm{NH}_{4}{ }^{*}(\mathrm{p}>0.05)$, but the correlation between potential nitrification and pore water $\mathrm{NO}_{3}^{-}$was significant in runnels $(\mathrm{p}<$ 0.05). The presence of nitrifying bacteria below the depth of $\mathrm{O}_{2}$ penetration in sediment suggests that mixing processes have a role in controlling nitrification in this mudflat.
\end{abstract}

KEY WORDS: Atlantic - Intertidal mudflats · Nitrification · Ridges · Runnels

\section{INTRODUCTION}

Nitrification, the microbial transformation of $\mathrm{NH}_{4}{ }^{+}$to $\mathrm{NO}_{2}{ }^{-}$and $\mathrm{NO}_{3}{ }^{-}$, is a key process in the nitrogen cycle of coastal waters because it is considered as the main source of $\mathrm{NO}_{3}{ }^{-}$available for denitrification in sediments (Seitzinger 1988). In the coupled process of nitrification-denitrification, $\mathrm{NO}_{3}{ }^{-}$originating from organic matter mineralization in the oxic layer of sediments is used as a terminal electron acceptor by denitrifying bacteria, producing gaseous forms of nitrogen $\left(\mathrm{N}_{2}\right.$, $\mathrm{N}_{2} \mathrm{O}$ ) which are essentially unavailable to most coastal phytoplankton (Howarth et al. 1988). This loss of nitrogen for the system can have a positive effect on the global nitrogen budget of estuarine and coastal areas by lowering eutrophication, but it can also affect negatively planktonic primary production (Nixon 1981). Nitrification has other important ecological implica-

•E-mail: geomario@aau.dk tions, both positive in the form of detoxification of high $\mathrm{NH}_{4}{ }^{+}$concentrations and lowering of $\mathrm{pH}$, and negative in that its consumption of $\mathrm{O}_{2}$ may contribute to anoxia in bottom waters (Murray \& Grundmanis 1980, Hall 1986).

The factors generally pointed out as influencing nitrification in sediments are temperature, $\mathrm{O}_{2}$ and $\mathrm{NH}_{4}{ }^{+}$ availability, and the abundance of nitrifying bacteria (Henriksen et al. 1981, Fenchel et al. 1998). In many sediments nitrification is limited by $\mathrm{O}_{2}$ concentration (Kaplan 1983) since $\mathrm{O}_{2}$ penetration can be limited to a few millimeters only.

There are several methods for measuring the process in intact sediment cores: (1) ${ }^{15} \mathrm{~N}$ methods (2) incorporation of ${ }^{14} \mathrm{CO}_{2}$ (3) use of nitrification inhibitors and measurement of the rate of $\mathrm{NH}_{4}{ }^{+}$accumulation. In ${ }^{15} \mathrm{~N}$ methods, where ${ }^{15} \mathrm{NH}_{4}{ }^{+}$is added to sediment microcosms, the measurement of the ${ }^{15} \mathrm{NH}_{4}{ }^{+}$content at the actual nitrification site is difficult (Nishio et al. 1983). Estimation of the in situ nitrification rate through incorporation of ${ }^{14} \mathrm{CO}_{2}$ is also difficult, because it depends 
on the nature of the organic matter and $\mathrm{NH}_{4}{ }^{+}$oxidizer populations, the $\mathrm{C}: \mathrm{N}$ ratio assimilated by these bacteria being quite variable (Billen 1976). When using nitrification inhibitors, the actual nitrification rate is given by the difference between the $\mathrm{NH}_{4}^{+}$build-up in inhibited and non-inhibited cores (Henriksen 1981). Nserve has often been used as nitrification inhibitor, but the long incubation time that it requires leads to an accumulation of variable $\mathrm{NH}_{4}{ }^{+}$pools in the sediment from which extraction is difficult (Laima unpubl. data). Methyl fluoride has also been used as nitrification inhibitor, but its efficiency is comparable to that of acetylene (Caffrey \& Miller 1995). It is known that acetylene quickly inhibits the oxidation of $\mathrm{NH}_{4}{ }^{+}$at concentrations $>10 \mathrm{~Pa}$ in pure culture by reacting with the $\mathrm{NH}_{4}{ }^{+}$monooxygenase (Bédard \& Knowles 1989). Since using acetylene as a nitrification inhibitor only requires a short incubation period, it is possible to detect short-term changes in the content of dissolved $\mathrm{NH}_{4}{ }^{+}$ (Sloth et al, 1992). Further, it is assumed that the application has no influence on nitrate reduction (Binnerup et al. 1992).

Intertidal mudflats, which occupy large areas in estuarine zones, are areas of intensive production and mineralization of organic matter. Although they have been recognized as playing an important role in benthic regeneration (Nedwell 1984, Feuillet-Girard et al. 1997) and in the primary productivity of overlying waters (Billen 1978), the nitrogen turnover in these coastal areas is still poorly understood, particularly in relation to their geomorphological features. Such mudflats are frequently characterized by major sedimentary structures known as 'ridges and runnels' i.e. a parallel succession of crests and troughs normal to shores (Dyer 1998). Ridges and runnels are quite different with respect to the $\mathrm{NH}_{4}{ }^{+}$adsorption onto the sediment matrix (Laima et al. 1999). Because these differences can affect many of the factors involved in the control of nitrification, such as $\mathrm{O}_{2}$ penetration and $\mathrm{NH}_{4}{ }^{+}$concentration, these structures should be considered when assessing nutrient regeneration in intertidal mudflats.

The present study investigates (1) the acetylene technique for measuring nitrification in waterlogged 'ridges and runnels' in Marennes-Oléron Bay, France, (2) the relative importance of geomorphological characteristics of this mudflat on nitrification rates, and (3) whether nitrification rates could be correlated with sediment variables such as $\mathrm{NH}_{4}{ }^{+}, \mathrm{NO}_{3}{ }^{-} \mathrm{O}_{2} \mathrm{pH}, \mathrm{E}_{\mathrm{h}}, \mathrm{C}$ and $\mathrm{N}$ contents.

\section{MATERIALS AND METHODS}

Study area. Marennes-Oléron Bay is located in the middle of the western coast of France and extends over about $170 \mathrm{~km}^{2}$ between Oléron Island and the mainland (Fig. 1). It includes large intertidal mudflats which cover about $110 \mathrm{~km}^{2}$ (Germaneau \& Sauriau 1996). The studied mudflat is the largest eastern mudflat where the 'ridge and runnel' area represents about half of the total surface area. These structures seem to be permanent with ridges occupying about $60 \%$ and runnels $30 \%$ of the surface area (Sauriau et al. 1996). A description of the hydrobiological characteristics of the bay can be found in Héral et al. (1983). The study area receives heavy inputs of detrital organic matter originating from land and ocean, and supports a high microphytobenthic biomass (Blanchard et al. 1998, Guarini et al. 1998).

Sampling and major analyses. Sampling took place in the upper part of the mudflat where the ridge-andrunnel system spreads over a $30 \mathrm{~km}^{2}$ area (see Fig. 1 and Germaneau \& Sauriau 1996). Twenty-two sediment cores $(5.4 \mathrm{~cm}$ i.d., $20 \mathrm{~cm}$ long) were taken by hand at low tide (tidal range of $5.5 \mathrm{~m}$ ) on May 6, 1997 , 11 covering about $6 \mathrm{~m}^{2}$ of surface area on a ridge and similarly a further 11 in an adjacent runnel. Collecting sites were chosen at random. Sediment cores were kept at low temperature and quickly transported to the laboratory. Six cores (3 ridges +3 runnels) were used for pore water extraction in the following way: surface water from each core was discarded, the sediment column was cut into $1 \mathrm{~cm}$ slices down to a depth of $5 \mathrm{~cm}$. A portion of sediment from each stratum (Series A) was purged in $\mathrm{N}_{2}$ and centrifuged $\left(3000 \times g, 10 \mathrm{~min}\right.$ at $\left.0^{\circ} \mathrm{C}\right)$ in gas-tight containers. Pore water extracts were filtered through GF/F filters ( $0.7 \mu \mathrm{m}$ of pore size) and frozen at $-20^{\circ} \mathrm{C}$ until analysis of $\mathrm{NH}_{4}{ }^{+}$and $\mathrm{NO}_{3}{ }^{-}$. The remaining portion (Series $\mathrm{B}$ ) was used in the assay of potential nitrification (see below). Four additional cores ( 2 ridges +2 runnels) were used for measurements of $\mathrm{E}_{\mathrm{h}}, \mathrm{pH}$, water content $\left(24 \mathrm{~h}\right.$ at $60^{\circ} \mathrm{C}$ ), bulk density, and $\mathrm{C}$ and $\mathrm{N}$ contents. The $\mathrm{pH}$ was measured using a pH meter (Knick Portamess 651-2, USA) and potentials using a saturated calomel electrode (Ingold $406 \mathrm{M6}$-S7) as reference and a Pt-electrode (4800 M5). The $\mathrm{pH}$ meter was calibrated before each new measurement. The C-N composition of sediment organic matter was determined using a CHN Carlo Erba 1500 analyser using acetanilide $(\mathrm{N}=10.39 \%$ and $\mathrm{C}=$ $71.09 \%$ ) as standard. Prior to the $\mathrm{C}-\mathrm{N}$ analysis, the sediment sample was acidified with $1 \mathrm{~N} \mathrm{HCl}$ to remove carbonates. This decarbonation was increased by sonification. The samples were then dried under vacuum to eliminate $\mathrm{HCl}$ vapours, after which $1 \mathrm{ml}$ of $\mathrm{Milli}-\mathrm{Q} \mathrm{H}_{2} \mathrm{O}$ was added. The samples were then homogenized by sonification and freeze-dried. Runnels are essentially draining structures covered by fluff containing an easily degradable fraction of organic matter and microphytobenthos. Ridges and runneis are similar with 


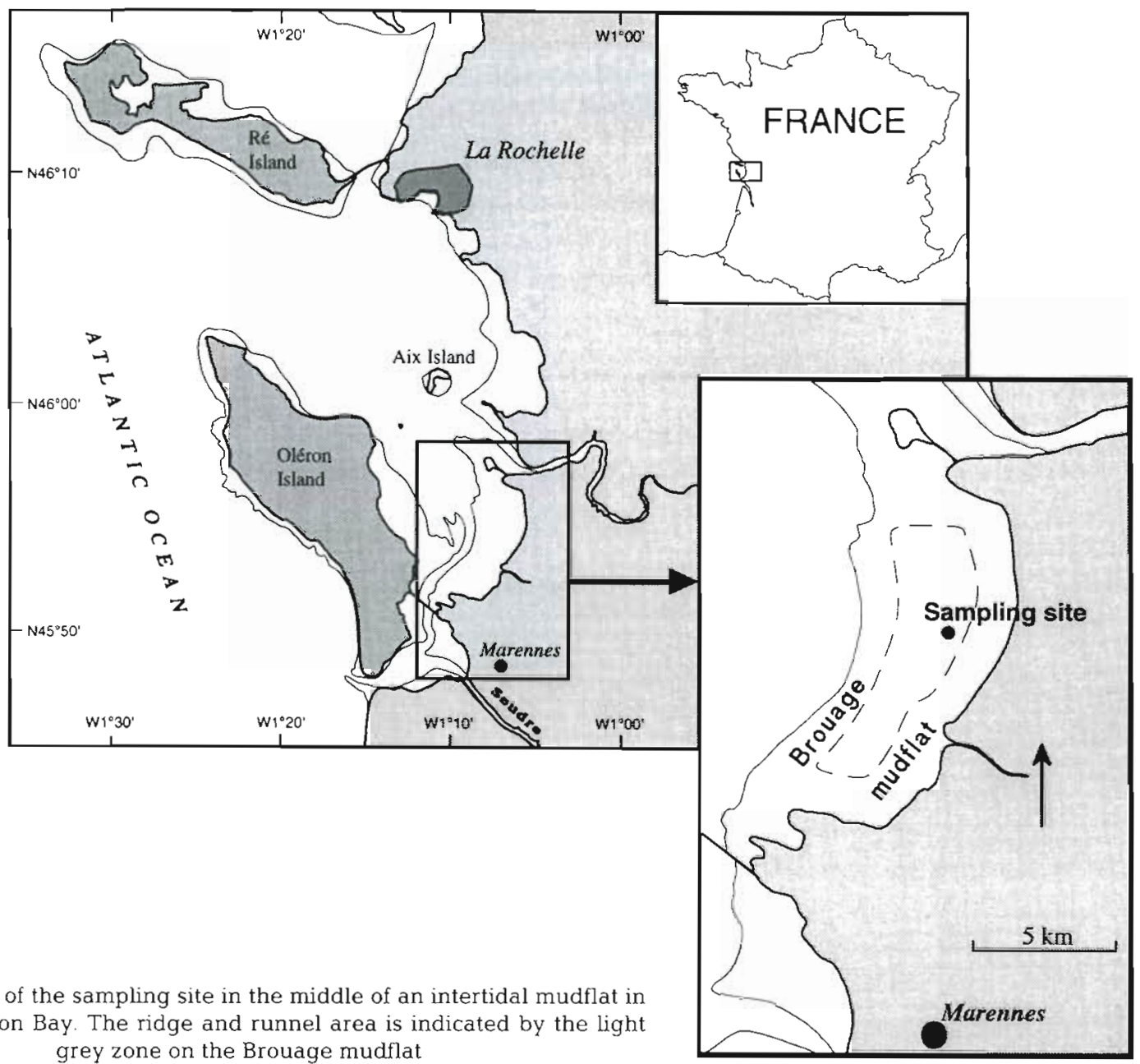

Fig. 1. Location of the sampling site in the middle of an intertidal mudflat in Marennes-Oléron Bay. The ridge and runnel area is indicated by the light grey zone on the Brouage mudflat

respect to their density and $\mathrm{C}$ and $\mathrm{N}$ contents, but differ considerably in some functional characteristics such as $\mathrm{H}_{2} \mathrm{O}$ content, $\mathrm{pH}$ and Eh (Table 1). Furthermore, primary fluxes estimated by ${ }^{7} \mathrm{Be}$ analysis in the shallow sediment horizons are around $20 \mathrm{~cm} \mathrm{yr}^{-1}$ in runnels and only $7 \mathrm{~cm} \mathrm{yr}^{-1}$ in ridges (Gouleau et al. in press)

Actual nitrification assays. The $\mathrm{NO}_{3}{ }^{-}$concentration in the water above sediments varied between 50 to $70 \mu \mathrm{M}$. Incubations under such high $\mathrm{NO}_{3}{ }^{-}$concentrations often result in variable $\mathrm{NH}_{4}{ }^{+}$pools in sediment from which their displacement is also variable (Laima unpubl.). To avoid these effects and to best assess the effect of acetylene on the $\mathrm{NH}_{4}{ }^{+}$efflux, incubations were carried out in the absence of $\mathrm{NO}_{3}{ }^{-}$in the overlying water. The water of 12 cores ( 6 runnels +6 ridges) was carefully replaced by $\mathrm{NO}_{3}{ }^{-}$-free artificial seawater of the same salinity, the water height was adjusted to $8 \mathrm{~cm}$ and cores were fitted with magnet stirrers and removeable gas-tight rubber membranes leaving no air phase (Fig. 2). Steady-state was obtained after $10 \mathrm{~h}$ of preincubation in the dark at the in situ temperature $\left(16^{\circ} \mathrm{C}\right)$. Sediment $\mathrm{O}_{2}$ consumption was then measured with a microelectrode (see below). The flux was calculated from the linear gradient above the sediment:

$$
J=D d\left[\mathrm{O}_{2}\right] / \mathrm{d} z
$$

where $J$ is the flux of $\mathrm{O}_{2}$ into the sediment, $z$ is the depth and $D$ is the diffusion coefficient for $\mathrm{O}_{2}$ in water at ambient salinity and temperature. Rate values were $0.05 \mathrm{mmol} \mathrm{O}_{2} \mathrm{~m}^{-2} \mathrm{~d}^{-1}$ for ridges and $0.14 \mathrm{mmol} \mathrm{O}_{2} \mathrm{~m}^{-2}$ $\mathrm{d}^{-1}$ for runnels (Table 2). Overlying water, which was stirred continuously, was sampled $(2.5 \mathrm{ml})$ after $0,3.3$, 6.2 , and $17.1 \mathrm{~h}$ and replaced by equal volumes of $\mathrm{O}_{2}-$ enriched water, to compensate for this consumption of $\mathrm{O}_{2}$. The concentration of $\mathrm{NH}_{4}{ }^{+}$was measured on each subsample. At Hour 22, acetylene-saturated water was added to the water phase of 8 cores ( 4 ridges +4 runnels) in a proportion of $1 \%$ (vol:vol). This relatively high concentration is sufficient to ensure complete inhibition and rapid diffusion to nitrification sites in the sediment (Sloth et al. 1992). Prior to use, acetylene was 
Table 1. Measurements of $\mathrm{H}_{2} \mathrm{O}$ content, bulk density, $\mathrm{pH}, \mathrm{E}_{h}, \mathrm{C}$ and $\mathrm{N}$ contents in 4 ridge and runnel cores sampled at MarennesOléron mudflat on May 6, 1997. Means and SDs are shown $(n=2)$. C and $N$ data are shown for 2 cores ( 1 ridge +1 runnel). Results of a $t$-test for dependent samples at $95 \%$ confidence interval are shown at the bottom of the table. ns: not significant; s: significant

\begin{tabular}{|c|c|c|c|c|c|c|c|}
\hline $\begin{array}{l}\text { Layer } \\
(\mathrm{cm})\end{array}$ & $\begin{array}{l}\mathrm{H}_{2} \mathrm{O} \\
(\%)\end{array}$ & $\begin{array}{l}\text { Bulk density } \\
\left(\mathrm{g} \mathrm{cm}^{-3}\right)\end{array}$ & $\mathrm{pH}$ & $E_{h}$ & $\begin{array}{c}C \\
\left(\mu g \mathrm{mg}^{-1}\right)\end{array}$ & $\begin{array}{c}\mathrm{N} \\
\left.(\mu \mathrm{g} \mathrm{mg})^{-1}\right)\end{array}$ & $\begin{array}{l}\mathrm{C} / \mathrm{N} \\
\text { ratio }\end{array}$ \\
\hline \multicolumn{8}{|c|}{ Ridges } \\
\hline $0-1$ & $119.4 \pm 8.3$ & $1.65 \pm 0.1$ & $7.01 \pm 0.0$ & $254 \pm 53$ & 11.54 & 1.67 & 6.9 \\
\hline $1-2$ & $108.3 \pm 2.1$ & $1.49 \pm 0.1$ & $6.92 \pm 0.1$ & $186 \pm 26$ & 10.85 & 1.58 & 6.9 \\
\hline $2-3$ & $112.6 \pm 2.4$ & $1.41 \pm 0.1$ & $6.90 \pm 0.0$ & $189 \pm 26$ & 10.59 & 1.56 & 6.8 \\
\hline $3-4$ & $91.9 \pm 7.1$ & $1.58 \pm 0.0$ & $7.02 \pm 0.1$ & $169 \pm 30$ & 12.56 & 1.99 & 6.3 \\
\hline $4-5$ & $96.9 \pm 6.2$ & $1.52 \pm 0.0$ & $7.07 \pm 0.0$ & $192+23$ & 10.72 & 1.56 & 6.9 \\
\hline \multicolumn{8}{|c|}{ Runnels } \\
\hline $0-1$ & $184.9 \pm 7.9$ & $1.28 \pm 0.1$ & $7.45 \pm 0.08$ & $218 \pm 20$ & 12.05 & 1.73 & 6.9 \\
\hline $1-2$ & $174.1 \pm 2.0$ & $1.42 \pm 0.0$ & $7.43 \pm 0.06$ & $126+22$ & 14.25 & 1.94 & 7.3 \\
\hline $2-3$ & $190.4 \pm 4.6$ & $1.44 \pm 0.1$ & $7.39 \pm 0.03$ & $119 \pm 22$ & 15.17 & 2.20 & 6.9 \\
\hline $3-4$ & $192.6 \pm 14.6$ & $1.34 \pm 0.0$ & $7.39 \pm 0.02$ & $96 \pm 7$ & 12.81 & 2.08 & 6.2 \\
\hline $4-5$ & $148.9 \pm 10.7$ & $1.38 \pm 0.1$ & $7.40 \pm 0.01$ & $110 \pm 8$ & 12.14 & 1.76 & 6.9 \\
\hline $\mathrm{p}$ & $0.0009 \mathrm{~s}$ & $0.083 \mathrm{~ns}$ & $0.0002 \mathrm{~s}$ & $0.001 \mathrm{~s}$ & $0.074 \mathrm{~ns}$ & $0.064 \mathrm{~ns}$ & 0.405 ns \\
\hline
\end{tabular}

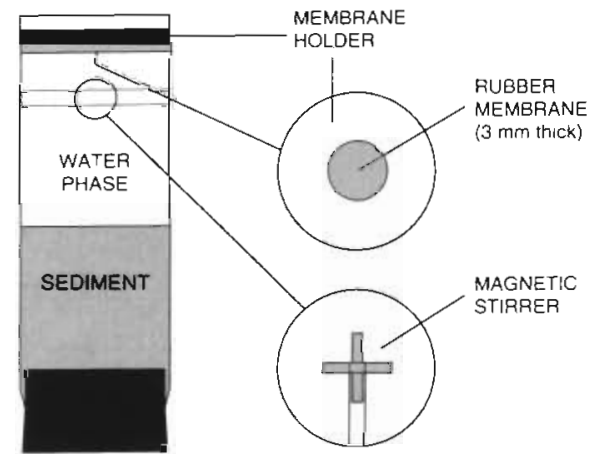

Fig. 2. Incubation cores: $54 \mathrm{~mm}$ acrylic tubes fitted with a tight, removable membrane on the top, a magnetic stirrer with adjustable position in the water phase, and a rubber stopper in the bottom. Stirring of overlying water was controlled by a central rotating magnet (not shown) trapped into $0.1 \mathrm{M}$ phosphoric acid to remove any contamination by $\mathrm{NH}_{4}{ }^{+}$. The water phase was further sampled at times $22.0,24.6,28.4,30.4$ and $32.6 \mathrm{~h}$ and equal volumes of $\mathrm{O}_{2}$ enriched water and acetylene enriched water were added as before. Samples were analysed for $\mathrm{NH}_{4}{ }^{+}$as before. Four cores (2 ridges +2 runnels) were incubated without acetylene to control the $\mathrm{NH}_{4}{ }^{+}$ efflux.

The acetylene blockage technique has a statistical advantage over other methods in that the same individual core serves for measuring $\mathrm{NH}_{4}{ }^{+}$fluxes before and after inhibition, so the flux variability among cores does not interfere with the measured rates. Therefore flux rates were calculated by linear regression using the $\mathrm{NH}_{4}^{+}$build-up in the overlying water from individual cores before and after acetylene addition. The actual nitrification rates were calculated as the difference between the $\mathrm{NH}_{4}^{+}$fluxes before and after inhibition in the same set of cores.

Table 2. Sediment $\mathrm{O}_{2}$ consumption, depth of $\mathrm{O}_{2}$ penetration, mineralization and nitrification rates in 'ridges' and 'runnels' from Marennes-Oléron Bay, France. $\mathrm{O}_{2}$ depth profiles before and after inhibition (1 ridge +1 . runnel) were measured at 2 positions situated only 1 to $2 \mathrm{~mm}$ apart. Rates are given as $\mathrm{mmol} \mathrm{m} \mathrm{m}^{-2} \mathrm{~d}^{-1}$

\begin{tabular}{|c|c|c|c|c|c|c|c|c|}
\hline \multirow[t]{2}{*}{ Structure } & \multicolumn{2}{|c|}{$\begin{array}{c}\mathrm{O}_{2} \text { penetration } \\
(\mathrm{mm})\end{array}$} & \multicolumn{2}{|c|}{$\mathrm{O}_{2}$ consumption } & \multirow{2}{*}{$\begin{array}{l}\text { Nitrification } \\
\text { measured }\end{array}$} & \multirow{2}{*}{$\begin{array}{c}\text { Net } \\
\text { mineral- } \\
\text { ization }\end{array}$} & \multirow{2}{*}{$\begin{array}{c}\% \text { of } \\
\text { nitrified } \\
\mathrm{NH}_{4}{ }^{+}\end{array}$} & \multirow[t]{2}{*}{$\mathrm{NO}_{3}^{-}$flux ${ }^{\mathrm{d}}$} \\
\hline & $-\mathrm{C}_{2} \mathrm{H}_{2}$ & $+\mathrm{C}_{2} \mathrm{H}_{2}$ & $-\mathrm{C}_{2} \mathrm{H}_{2}$ & $+\mathrm{C}_{2} \mathrm{H}_{2}$ & & & & \\
\hline Ridge & 2.4 & 1.2 & 0.05 & 0.09 & $0.21 \pm 0.20$ & 0.29 & 72 & $<0.005$ \\
\hline Runnel & 1.3 & 0.6 & 0.14 & 0.007 & $1.27 \pm 0.45$ & 1.66 & 76 & $<0.005$ \\
\hline
\end{tabular}


Fluxes $(F)$ of $\mathrm{NO}_{3}{ }^{-}$at the sediment-water interface were calculated as

$$
\mathrm{FNO}_{3}{ }^{-}=\alpha V A^{-1}
$$

where $\alpha$ is the slope of the regression line obtained by plotting the overlying water $\mathrm{NO}_{3}{ }^{-}$concentration $(\mu \mathrm{M})$ as a function of the incubation time (h), $V$ is the volume of the water column $\left(\mathrm{cm}^{3}\right)$, and $A$ is the core surface area $\left(\mathrm{cm}^{2}\right)$. A positive flux means that the solute is liberated from the sediment towards the overlying water. In some cores small Hydrobia sp. (diam. around $0.2 \mathrm{~cm}$ ) were present in the sub-layers below $0.5 \mathrm{~cm}$ of the sieved runnel sediment at concentrations ranging from 0.4 to 2.8 individuals $\mathrm{cm}^{-3}$ of wet sediment. Data obtained from these cores were not used in the flux calculations

Nitrification potential assays. NP was determined using those pooled sediment samples (Series B, see above) from which a portion was also used for pore water removal. Samples (ca $1 \mathrm{~cm}^{3}$ ) in duplicate from each layer were sieved through a $1.5 \mathrm{~mm}$ mesh to remove large detritus and macrofauna, and the sieved sediment was shaken in $100 \mathrm{ml}$ incubation flasks with $50 \mathrm{ml}$ of artificial sea water at the same salinity and enriched with $1 \mathrm{mM} \mathrm{NH}_{4} \mathrm{Cl}$. A control set was prepared without $\mathrm{NH}_{4}{ }^{+}$enrichment. The slurries were gently shaken aerobically (Henriksen et al. 1981, Joye \& Hollibaugh 1995, Mayer et al. 1995) at the in situ temperature $\left(16^{\circ} \mathrm{C}\right)$ and in the dark. Five water samples per core were taken during a $24 \mathrm{~h}$ period, filtered through sterilized $\mathrm{GF} / \mathrm{F}$ filters and stored at $-20^{\circ} \mathrm{C}$ until analysis for $\mathrm{NO}_{3}^{-}$. From a linear increase of $\mathrm{NO}_{3}{ }^{-}$concentration with time, the slope of the regression line gives the potential nitrification rate. This rate is presumably proportional to the number of nitrifying bacteria (Henriksen 1981).

Sediment $\mathrm{O}_{2}$ profiles. Oxygen was measured in the water overlying the sediment and in pore water using a microelectrode (Diamond $737 \mathrm{GC}$ ). Prior to measurements, the microelectrode was calibrated in $\mathrm{O}_{2}$-saturated water $(100 \%)$ and in anaerobic sediment $10 \%)$. The electrode was mounted on a micromanipulator and placed into the water the electrode output signal was read through a picoammeter (Keithley 485) and sent to a computer. The microelectrode was then carefully pressed down in $20 \mu \mathrm{m}$ steps starting a few $\mathrm{mm}$ above the sediment surface and stable output signals were read at each depth interval. A second depth $\mathrm{O}_{2}$ profile was measured at the end of incubation at a position situated only 1 to $2 \mathrm{~mm}$ away from the first one.

A second expression used to calculate $\mathrm{O}_{2}$ consumption rate is (Cai \& Sayles 1996):

$$
F^{0} \mathrm{O}_{2}=F \mathrm{O}_{2}(z=0)-D_{\mathrm{s}} \mathrm{d}\left[\mathrm{O}_{2}\right] / \mathrm{d} z=D_{\mathrm{s}}\left[\mathrm{O}_{2}\right]_{\mathrm{bw}} / L
$$

where $L$ is the $\mathrm{O}_{2}$ penetration depth, $D_{5}$ is the $\mathrm{O}_{2}$ diffusivity in sediment pore water, $\left[\mathrm{O}_{2}\right]_{\text {bw }}$ the bottom water $\mathrm{O}_{2}$ concentration, $z$ is the depth and $\mathrm{FO}_{2}$ the $\mathrm{O}_{2}$ flux into the sediment. The $\mathrm{O}_{2}$ penetration depth can be calculated as follows:

$$
L=2 \phi D_{\mathrm{s}}\left[\mathrm{O}_{2}\right]_{\mathrm{bw}} / F^{0} \mathrm{O}_{2}
$$

where $\phi$ is the sediment porosity. Eqs. (3) \& (4) are intrinsically different: whereas Eq. (3) is based on a linear $\mathrm{O}_{2}$ concentration decrease, Eq. (4) implies $\mathrm{O}_{2}$ concentration follows a second order polynomial. An extrapolation of the derivative (a tangent line) at the sediment-water interface to $\left[\mathrm{O}_{2}\right]=0$ intersects the depth axis at $\Delta z$, and $F^{0} \mathrm{O}_{2}=-\phi D_{\mathrm{s}} 0-\left[\mathrm{O}_{2}\right]_{\mathrm{bw}} / \Delta z$. Substituting this relationship into Eq. (4) gives:

$$
L=2 \Delta z
$$

Eq. (3) assumes a linear gradient, but underestimates true $\mathrm{O}_{2}$ penetration by a factor of 2 , and thus Eq. (4) is best suited to benthic chamber measurements. When calculating the flux from $\mathrm{O}_{2}$ gradients measured by microelectrodes, and in order to avoid the need to specify $\phi$ and $D_{s}$, a slightly different form of Eq. (3) is more appropriate.

Since $F^{0} \mathrm{O}_{2}=-\phi D_{\mathrm{s}}\left(\mathrm{O}_{2} \text { gradient }\right)_{z=0}$. Eq. (4) may be re-written as:

$$
L=2\left[\mathrm{O}_{2}\right]_{b \mathrm{w}} /\left(\mathrm{O}_{2} \text { gradient }\right)_{z=0}
$$

Chemical analyses and calculations. Ammonium was measured manually using the salicylate method with minor modifications (Laima 1992). Nitrate and nitrite were measured using a Skalar autoanalyser. Concentration data were corrected for dilution effects. Variance and correlation analyses at $95 \%$ confidence interval were carried out using STATISTICA (StatSoft Inc. 1993).

\section{RESULTS AND DISCUSSION}

Prior to acetylene addition, the $\mathrm{NH}_{4}{ }^{+}$efflux increased with time in both cases and the differences in slope between sample and controls were not significant $(\mathrm{p}>$ 0.05) (Fig. 3). As expected, the $\mathrm{NH}_{4}^{+}$efflux increased comparatively after addition of acetylene to the overlying water. $\mathrm{NH}_{4}{ }^{+}$oxidation was effectively inhibited as the overlying water $\mathrm{NO}_{3}^{-}$concentration did not increase after the moment of acetylene addition (not shown). Nitrification rates were calculated for individual cores using the $\mathrm{NH}_{4}{ }^{+}$efflux data (Fig. 3) and rates are shown as means \pm SDs among cores for both structures (Table 2). To test for statistical equality between the means, a $t$-test of the difference between 2 means was used (Sokal \& Rohlf 1981). Differences in rate between ridges $\left(0.21 \pm 0.20 \mathrm{NO}_{3}{ }^{-} \mathrm{mmol} \mathrm{m} \mathrm{m}^{-2} \mathrm{~d}^{-1}\right)$ and 

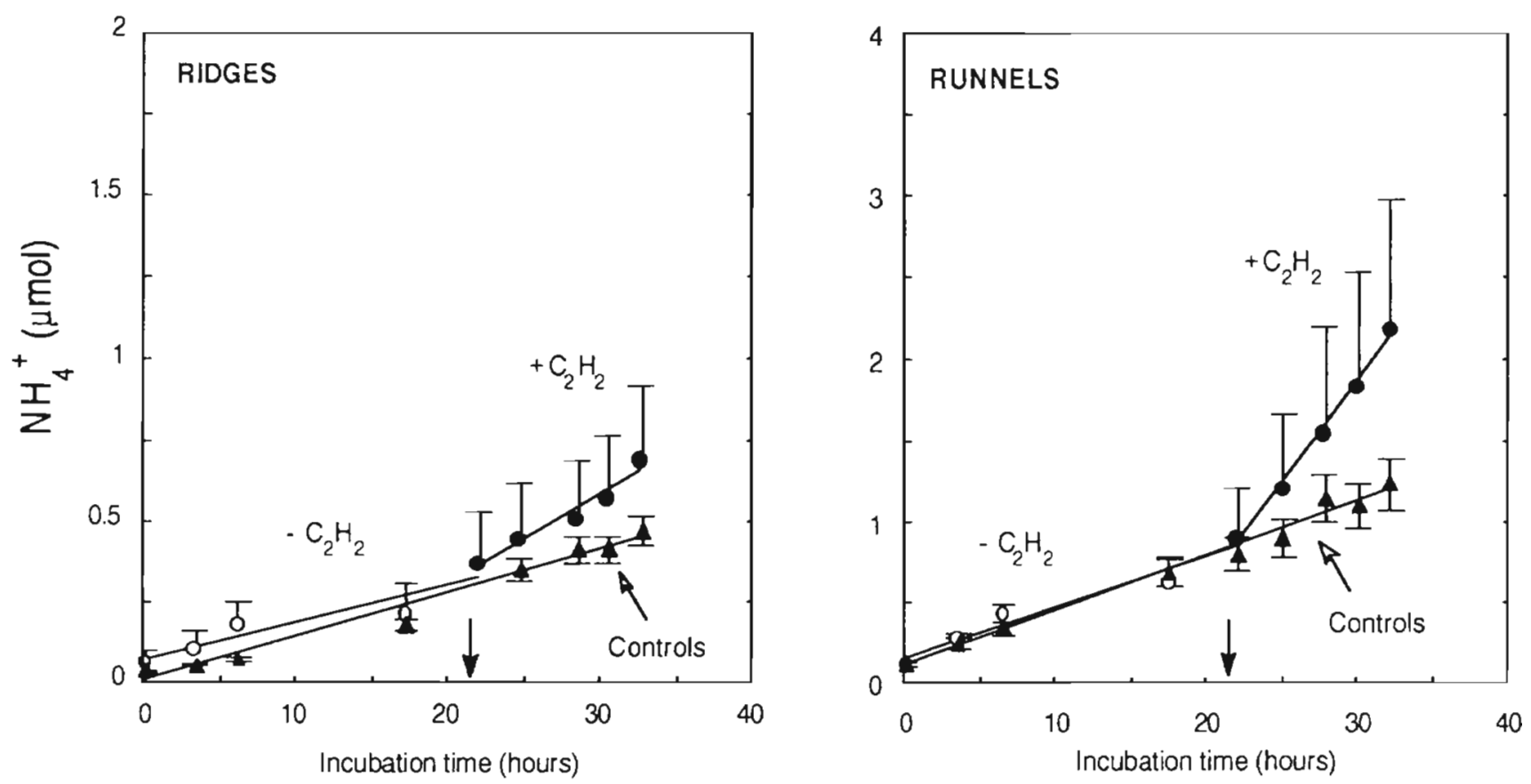

Fig. 3. Molar accumulation of $\mathrm{NH}_{4}{ }^{+}$in the water phase of incubated cores. The slopes of regression lines give the $\mathrm{NH}_{4}{ }^{+}$accumulation rates before inhibition (empty circles, $\mathrm{n}=7$ ) and after inhibition on the same cores (full circles). The arrow indicates the time of addition of acetylene-enriched water to the overlying water. Control cores without acetylene addition (full triangles, $\mathrm{n}=4$ ) were run for checking the $\mathrm{NH}_{4}{ }^{+}$flux

runnels $\left(1.27 \pm 0.45 \mathrm{NO}_{3}^{-} \mathrm{mmol} \mathrm{m}{ }^{-2} \mathrm{~d}^{-1}\right)$ was significant $(\mathrm{p}<0.05)$. Actual nitrification (AN) rates in the individual cores ranged from 0.1 to $0.3 \mathrm{mmol} \mathrm{NO}_{3}{ }^{-} \mathrm{m}^{-2} \mathrm{~d}^{-1}$ in ridges and from 0.7 to $1.6 \mathrm{NO}_{3}^{-} \mathrm{mmol} \mathrm{m}^{-2} \mathrm{~d}^{-1}$ in runnels. These AN rates are in close agreement with those given by the $\mathrm{N}$-serve method at the same site in late winter $\left(0.50\right.$ to $0.84 \mathrm{mmol} \mathrm{NO}_{3}^{-} \mathrm{m}^{-2} \mathrm{~d}^{-1}$, Feuillet-Girard unpubl. data) and comparable to those reported for other shallow marine environments (Nishio et al. 1983, Kemp et al. 1990).

Potential nitrification (PN) rates turned out to be significantly higher in runnels than in ridges $(p<0.05)$ (Fig. 4). PN rates decreased slightly with depth in both structures and a peak was detected in the 2 to $3 \mathrm{~cm}$ layer of runnels. The rates did not significantly correlate $(p>0.05)$ with any of the parameters listed in Table 1. Nitrification potential has been shown to reflect changes in bacterial number rather than changes in specific activity (Hansen et al. 1981). This may indicate that nitrifying bacteria are relatively more abundant in runnels than in ridges despite the stronger reducing conditions that prevail below the top $1 \mathrm{~cm}$ in runnels $\left(E_{h}\right.$ data in Table 1$)$. Once burried in the reduced sediment, nitrifying bacteria are known to survive for at least 1 mo (Hansen et al. 1981). Although the nitrifying bacteria are present down to a depth of $5 \mathrm{~cm}$ land hence there is a nitrifi- cation potential), actual nitrification is only possible in the top $1 \mathrm{~cm}$ where $E_{h}$ is higher than $200 \mathrm{mV}$ (based on Vanderborght \& Billen's 1975 and Mortimer's 1942 criterium). The observed vertical PN pattern (essentially in runnels) might be a result of intense mixing processes occurring here.

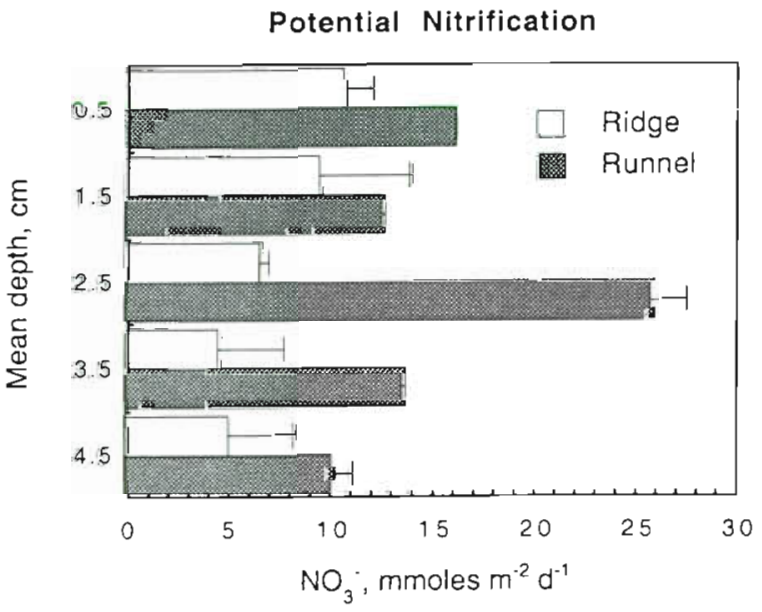

Fig. 4. Nitrification potentials ( $m m o l \mathrm{~m}^{-2} \mathrm{~d}^{-1}$ ) in the surficial $(0$ to $5 \mathrm{~cm})$ horizons of ridges and runnels $(\mathrm{n}=2)$. SD is also indicated 

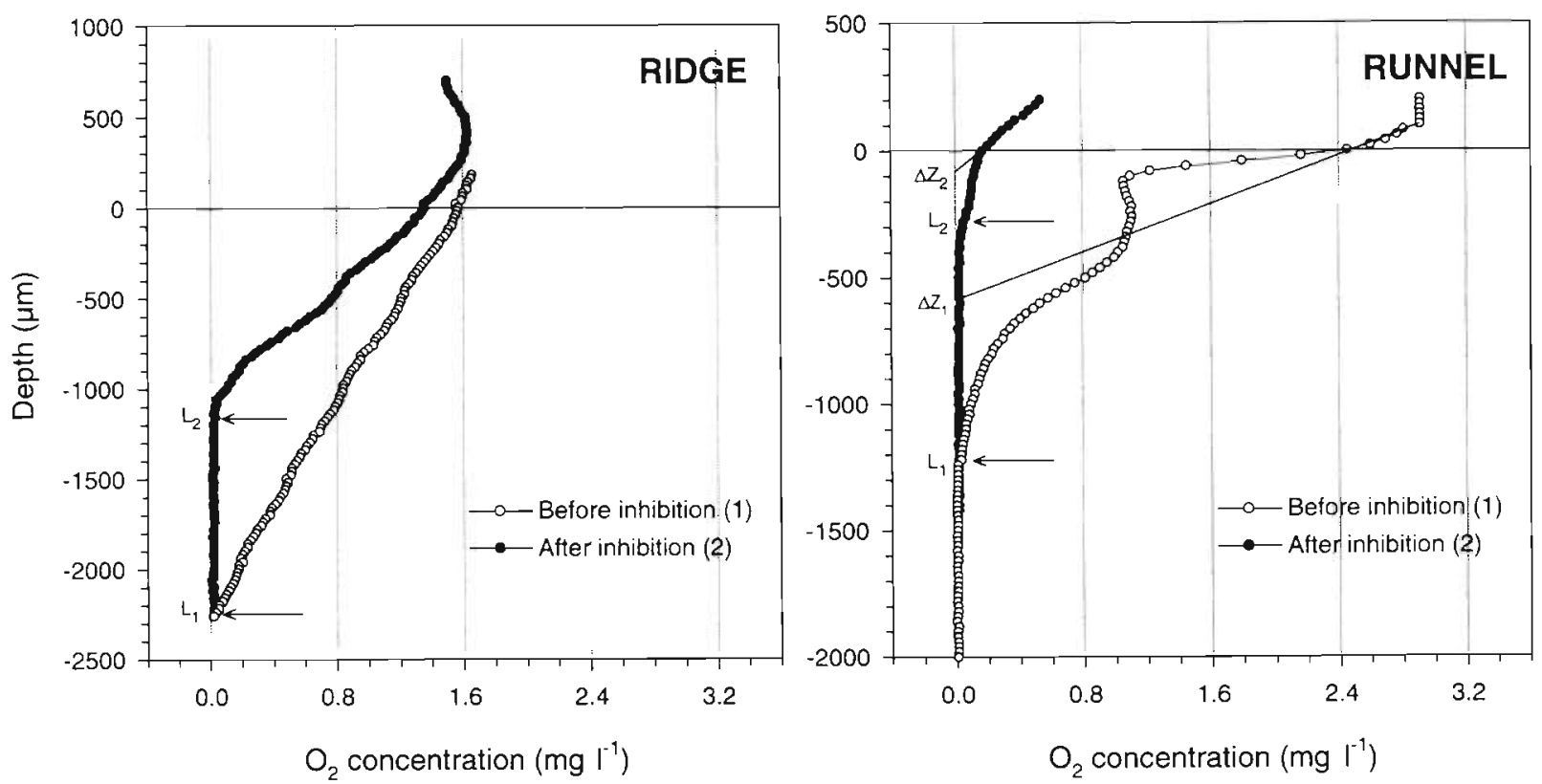

Fig. 5. Pore water $\mathrm{O}_{2}$ profiles measured before and after ( 1 to $2 \mathrm{~mm}$ apart) acetylene addition to the overlying water. $\Delta z$ is the $x$-coordinate intercept of the line extrapolated from the derivative of the $\mathrm{O}_{2}$ profile at the interface. $\mathrm{L}_{1}$ and $\mathrm{L}_{2}$ are the $\mathrm{O}_{2}$ penetration depths before and after inhibition, respectively. In runnel, the tangent line and therefore $\Delta z$ was determined from the fit of an exponential equation to the top 10 data points. In ridge, Eq. (5) did not apply and the $\mathrm{O}_{2}$ penetration depth was taken as the depth where the $\mathrm{O}_{2}$ electrode signal was around $1 \%$ of the bottom water value. This is because the electrode behaviour changes at very low oxygen concentration in reduced sediments (Revsbech \& Jørgensen 1986)

The $\mathrm{O}_{2}$ profiles before and after inhibition were markedly different (Fig. 5). During emersion, ridges are frequently exposed to air and the $\mathrm{O}_{2}$ penetration depth is thus likely to increase as a result of drying. In such conditions, nitrifying bacteria must adapt or prefentially inhabit micro environments where small $\mathrm{O}_{2}$ fluctuations are best suited to their metabolism. In favour of this hypothesis is the presence of a $\mathrm{NO}_{3}{ }^{-}$peak at 2 to $3 \mathrm{~cm}$ depth in ridges in contrast to the profile in runnels (Fig. 6). In runnels, a secondary $\mathrm{O}_{2}$ maximum at $0.3 \mathrm{~mm}$ depth was measured (Fig. 5). Since all incubations were carried out in the absence of light, the gradient above $0.3 \mathrm{~mm}$ depth is unlikely to be due to photosynthesis, and was not used to calculate the $\mathrm{O}_{2-}$ flux. Also, given a high net $\mathrm{O}_{2}$ uptake closer to the surface, a photosynthetic maximum at this depth is unlikely. It is more likely that the microelectrode passed a worm burrow or something similar. Apparently, acetylene enhanced the $\mathrm{O}_{2}$ demand in the sublayers of both sediments.

The sediment nitrification zone is oxic and in close diffusional contact with the $\mathrm{O}_{2}$ (and acetylene) from the overlying water. Nitrifying bacteria are strictly aerobic and therefore the depth of $\mathrm{O}_{2}$ penetration is a good estimate for the nitrification zone in the sediment. It was not possible to accurately measure the true $\mathrm{O}_{2}$ penetration depth because $\mathrm{O}_{2}$ concentrations were very low. Using Eq. (6) gave $\mathrm{O}_{2}$ penetration depths before/after inhibition of $2.4 / 1.2 \mathrm{~mm}$ for ridge and 1.3/0.6 mm for runnel (Table 2). Assuming that other processes were not affected by the acetylene, the blockage of nitrification predicts a decreased $\mathrm{O}_{2}$ demand and hence a deeper $\mathrm{O}_{2}$ penetration in the

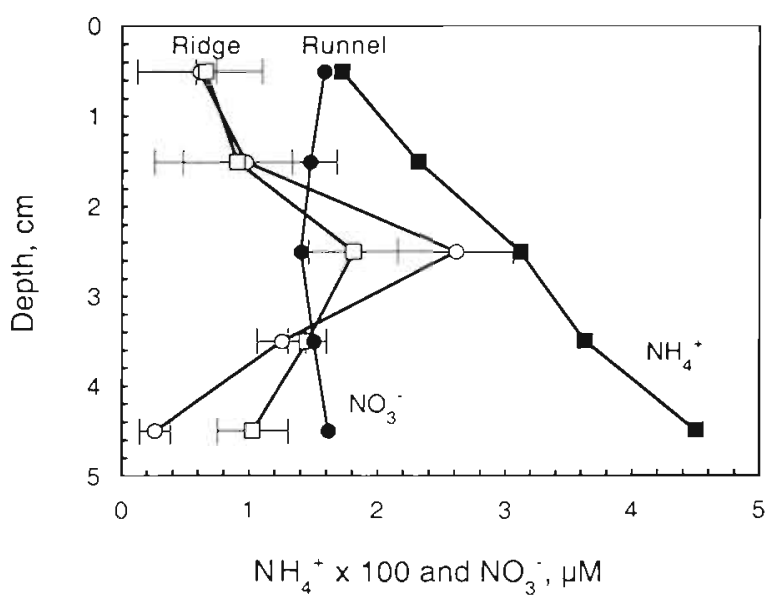

Fig. 6. Pore water concentrations of $\mathrm{NH}_{4}{ }^{+}$(squares) and $\mathrm{NO}_{3}{ }^{-}$ (circles) in ridges (empty symbols) and runnels (full symbols). Results for $\mathrm{NO}_{3}{ }^{-}$are shown as means and SDs $(\mathrm{n}=3)$. Concentration units are $\mu \mathrm{M}$ 
sediment. However, this situation was not observed in either of these structures. There is evidence (Fig. 6) suggesting that acetylene was non-specific in the blockage of nitrification because the $\mathrm{O}_{2}$ demand was enhanced differently in micro horizons below the sediment surface. To the authors' knowledge, such effects have not been reported to date in the literature. This 'non-specific' behaviour of acetylene is nevertheless to be expected because the sources for labile organic matter in this mudflat are quite variable in both time and space (Galois et al. in press). This substrate variability is likely to promote rapid changes in the mixed microbial populations that will react differently to acetylene. In any case, the decrease of the oxic zone thickness had nowhere near the same relative impact on the $\mathrm{O}_{2}$ consumption ( $\mathrm{Eq} .1$ ) in the ridge as it did in the runnel (Table 2).

The specific role of $\mathrm{O}_{2}$ on the nitrification is difficult to assess: It was found earlier that the microbial oxidation of $\mathrm{NH}_{4}{ }^{+}$stops at $\mathrm{O}_{2}$ concentrations between 1.1 and $6.2 \mu \mathrm{M}$ (Jørgensen et al. 1984) and that the process is inhibited between 2 to 3 times air saturation in an estuarine environment (Henriksen \& Kemp 1988). Kemp et al. (1990) found that nitrification was absent when $\mathrm{O}_{2}$ concentrations in the overlying water declined below $125 \mu \mathrm{M}$ and sediments were anoxic. Focht \& Verstraete (1977) found that the nitrification activity in pure culture continued even at very low $\mathrm{O}_{2}$ concentrations. However, heterotrophic bacteria have a much higher affinity for $\mathrm{O}_{2}\left(K_{m}<1 \mu \mathrm{M} \mathrm{O} \mathrm{O}_{2}\right)$ at low $\mathrm{O}_{2}$ concentrations and are hence likely to outcompete nitrifying bacteria. Heterotrophic bacteria are therefore likely to predominate in the suboxic sediment layers under these conditions (Fig. 6). Thus, the rate of nitrification in these sediments was apparently not related to the thickness of the oxic layer, and this is in agreement with other reports (Lohse et al. 1993).

Considering the $\mathrm{NH}_{4}{ }^{+}$flux after inhibition (second part of the slope Fig. 3 after the breakpoint) as an estimate of the net $\mathrm{N}$-mineralization, it turns out that the actual nitrification rates represent about $72 \%$ of the net $\mathrm{N}$ mineralization in ridges and $76 \%$ in runnels (Table 2). This $\mathrm{NO}_{3}{ }^{-}$is potentially available for $\mathrm{NO}_{3}{ }^{-}$ ammonification and denitrification and despite the difference in nitrification rate between the structures (a factor of 6 in favour of runnels), their nitrification potentials lie in the same range. These data therefore suggest that $\mathrm{NO}_{3}{ }^{-}$-reducing processes are important in this mudflat and deserve attention in future reseach. Further, the presence of nitrifying bacteria below $2.4 \mathrm{~mm}$ (ridge) and $1.3 \mathrm{~mm}$ (runnel) as indicated by nitrification potentials down to a depth of $5 \mathrm{~cm}$ (Fig. 4), suggests the importance of mixing processes in nitrification in the Marennes-Oléron mudflat. Nitrification was found to be significantly influenced by the ridge and runnel structures in intertidal mudflats. Therefore, such geomorphological structures at the scale of a whole mudflat must be taken into account when assessing the flux of dissolved matter at the ecosystem level.

Acknowledgements. We are indebted to the Region PoitouCharentes (contract no. 96/RPC-R 115), to Lucette Joassard and Françoise Mornet (CREMA) for providing technical support, to 3 anonymous reviewers for providing a good criticism of an earlier version of the manuscript and to Conrad AubRobinson for improving the English. We thank the Science and Technology Programme from JNICT for financial support during the writing phase of this project.

\section{LITERATURE CITED}

Bédard C, Knowles R (1989) Physiology, biochemistry and specific inhibitors of $\mathrm{CH}_{4}, \mathrm{NH}_{4}{ }^{+}$and $\mathrm{CO}$ oxidation by methanotrophs and nitrifiers. Microb Rev 53:68-84

Billen G (1976) Evaluation of nitrifying activity in sediments by dark ${ }^{14} \mathrm{C}$-bicarbonate incorporation. Water Res 10 : $51-57$

Billen G (1978) A budget of nitrogen recycling in North Sea sediments off the Belgian coast. Estuar Coast Shelf Res 7 : $127-146$

Binnerup SJ, Jensen K, Revsbech NP, Jensen MH, Sørensen J (1992) Denitrification, dissimulatory reduction of nitrate to ammonium and nitrification in a bioturbated estuarine sediment as measured with ${ }^{15} \mathrm{~N}$ and microsensor techniques. Appl Environ Microbiol 58:303-313

Blanchard GF, Guarini JM, Bacher C, Huet V (1998) Control of the short-term dynamics of intertidal microphytobenthos by the exondation-submersion cycle. CR Acad Sci Paris, Ser 3, Sci Vie/Life Sci 321:501-508

Caffrey JM, Miller LG (1995) A comparison of two nitrification inhibitors used to measure nitrification rates in estuarine sediments. FEMS Microb Ecol 17:213-220

Cai WJ, Sayles FL (1996) Oxygen penetration depths and fluxes in marine sediments. Mar Chem 52:123-131

Dyer KR (1998) The morphological development of intertidal mudflats. 2nd Annual Report, European Commission, Directorate General XII, MAST III, Contract MAS 3CT95-0022 Univ Plymouth, Plymouth, UK

Fenchel T, King GM, Blackburn TH (1998) Bacterial Biogeochemistry: The Ecophysiology of Mineral Cycling. Academic Press, San Diego

Feuillet-Girard M, Gouleau D, Blanchard G, Joassard L (1997) Nutrient fluxes on an intertidal mudflat in MarennesOléron Bay, and influence of the immersion period. Aquat Liv Resour 10:49-58

Focht DD, Verstraete W (1977) Biochemical ecology of nitrification and denitrification. Adv Microbial Ecol 1:135-214

Germaneau J, Sauriau PG (1996) La mer des pertuis: un système topographique filtrant les agents météo-océaniques. Bul Soc Sci Nat 8:53-67

Gouleau D, Jouanneau JM, Weber O, Saurian PG (in press) Short- and long-term sedimentation Montportail-Brouage intertidal mudflat, Marennes-Oléron Bay. France

Guarini JM, Blanchard GF, Bacher C, Gros P, Riera P, Richard P. Gouleau D, Galois R, Prou J, Sauriau P (1998) Dynamics of spatial patterns of microphytobenthic biomass: inferences from a geostatical analysis of two comprehensive surveys in Marennes-Oléron Bay (France). Mar Ecol Prog Ser 16:131-141 
Hall GH (1986) Nitrification in lakes. In: Prosser JI (ed) Nitrification. IRL Press, Oxford, p 127-156

Hansen JI, Henriksen K, Blackburn TH (1981) Seasonal distribution of nitrifying bacteria and rates of nitrification in coastal marine sediments. Microb Ecol 7:297-304

Henriksen. K (1981) Measurement of in situ rates of nitrification in sediment. Microb Ecol 6:329-337

Henriksen K, Kemp WM (1988) Nitrification in estuarine and coastal marine sediments: Methods, patterns and regulating factors. In: Blackburn TH, Sørensen J (eds) Nitrogen cycling in coastal marine environments. SCOPE 33, John Wiley, Chichester, p 207-249

Henriksen K, Hansen JI, Blackburn T (1981) Rates of nitrification, distribution of nitrifying bacteria, and nitrate fluxes in different types of sediment from Danish waters. Mar Biol 61:299-304

Héral M, Razet D, Deslous-Paoli JM, Berthome JP, Garnier J (1983) Caractéristiques saisonnières de l'hydrobiologie du complexe estuarien de Marennes-Oléron (France). Rev Trav Inst Pèches Marit 46:97-119

Howarth RW, Marino R, Lane J, Cole J (1988) Nitrogen fixation in freshwater, estuarine and marine ecosystems. I. Rates and importance. Limnol Oceanogr 33:669-687

Jørgensen KS, Jensen UB, Sørensen J (1984) Nitrous oxide production from nitrification and denitrification in marine sediment at low oxygen concentrations. Can J Microbiol 30:1073-1078

Joye SB, Hollibaugh JT (1995) lnfluence of sulfide inhibition of nitrification on nitrogen regeneration in sediments. Science 270:623-625

Kaplan WA (1983) Nitrification. In: Carpenter EJ, Capone DG (eds) Nitrogen in the marine environment. Academic Press, New York, p 139-190

Kemp WM. Sampou P, Caffrey J, Mayer M (1990) Ammonium recycling versus denitrification in Chesapeake Bay sediments. Limnol Oceanogr 35:1545-1563

Laima MJC (1992) Evaluation of the indophenol method to measure ammonium in extracts from coastal marine sediments. Mar Chem 39:283-296

Laima MJC, Feuillet-Girard M, Vouvé F, Blanchard G, Gouleau D, Galois R, Richard P (1999) Distribution of adsorbed ammonium pools in two intertidal sedimentary structures, Marennes-Oléron Bay, France. Mar Ecol Prog Ser 182:29-35

Lohse L, Malschaert JFP, Slomp CP, Helder W, Raaphorst W

Editorial responsibility: Otto Kinne (Editor),

Oldendorf/Luhe, Germany
(1993) Nitrogen cycling in North Sea sediments: interaction of denitrification and nitrification in offshore and coastal areas. Mar Ecol Prog Ser 101:283-296

Mayer SM, Schaffner L, Kemp WM (1995) Nitrification potentials of benthic macrofaunal tubes and burrow walls: effects of sediment $\mathrm{NH}_{4}{ }^{+}$and animal ir rigation behaviour. Mar Ecol Prog Ser 121:157-169

Mortimer CH (1942) The exchange of dissolved substances between mud and water in lakes. J Ecol 30:147-201

Murray JW, Grundmanis V (1980) Oxygen consumption in pelagic marine sediments. Science 209:1527-1530

Nedwell DB (1984) The input and mineralization of organic carbon in anaerobic aquatic sediments. Adv Microb Ecol $7: 93-131$

Nishio T, Koike I, Hattori A (1983) Estimates of denitrification and nitrification in coastal and estuarine sediments. Appl Environ Microbiol 45:444-450

Nixon (1981) Freshwater inputs and estuarine productivity. In: Cross RD, Williams DL (eds) Proceedings of the National Symposium on Freshwater Inflow to Estuaries. US Fish and Wildlife Service, Office of Biological Services, FWS/OBS.81/04, Washington DC, Vol. 1, p 31-57

Revsbech NP, Jørgensen BB (1986) Microlectrodes: their use in microbial ecology. In: Marshall KC (ed) Adv Microb Ecol 9. Plenum, New York, p 293-351

Sauriau PG, Germaneau J, Morin K, Robert S (1996) Zonation scheme of bedform structure from Brouage mudflat in the Marennes-Oléron Bay (Atlantic coast, France) in the morphological development of intertidal mudflats. 1st Annual Report, European Commission Directorate General XII, Mast III, Intmud, Contact MAS 3-CT95-0022, Univ Plymouth

Seitzinger SP (1988) Denitrification in freshwater and coastal marine sediments. Part 2. Ecological and geochemical significance. Limnol Oceanogr 33:702-724

Sloth NP, Nielsen LP, Blackburn TH (1992) Nitrification in sediment cores measured with acetylene inhibition. Limnol Oceanogr 37:1108-1112

Sokal RR, Rohlf FJ (1981) Biometry, 2nd edn. WH Freeman and $\mathrm{Co}$, San Francisco

VanderBorght JP, Billen G (1975) Vertical distribution of nitrate concentration in interstitial water in marine sediments with nitrification and denitrification. Limnol Oceanogr 20:953-961

Submitted: February 16, 1999; Accepted: July 13, 1999

Proofs received from author(s): December 9, 1999 